From the Department of Food Hygiene, National Veterinary Institute, Helsinki, Finland.

\title{
Pre-Enrichment and Enrichment Methods for Isolating Small Number of Campylobacteria from Contaminating Flora
}

\author{
By Matti Aho, Maija Kauppi and Jorma Hirn
}

\begin{abstract}
Aho, M., M. Kauppi and J. Hirn: Pre-enrichment and enrichment methods for isolating small number of campylobacteria from contaminating flora. Acta vet. scand. 1988, 29, 443-449. - A method was developed to detect fewer than 100 CFU of campylobacteria from SIFF transport medium to which thawing drip from deep frozen broiler carcasses was added as a source of contamination and which was then stored at room temperature for $20 \mathrm{~h}$. The method was made possible by using pre-enrichment in $1 \%$ buffered peptone water under a microaerophilic atmosphere for $5 \mathrm{~h}$ at $43^{\circ} \mathrm{C}$ before selective enrichment either in brucella enrichment broth and on brucella blood selective agar supplemented with Skirrow antibiotics or in CCD enrichment broth and on blood free CCD selective agar. The other pre-enrichment broth studied was alkaline peptone water with reducing agents (RAPW) and the other enrichment broths and selective agars were Preston broth and agar, THAL broth and alkaline tryptose broth (ATB) and brucella agar with ATB antibiotics. Contaminating flora can be a problem when using enrichment broths and selective agars with limited antibiotic supplementation.
\end{abstract}

microbiological methods; food hygiene; diagnostic procedures; selective media.

\section{Introduction}

Campylobacteria have very narrow optimum growth limits. Various physical and chemical factors control their growth: temperature, oxygen concentration, water activity, $\mathrm{NaCl}, \mathrm{pH}$ and disinfectants (Doyle 1984). Campylobacteria can withstand various stress-inducing factors if there is a high protein concentration in their environment (Hänninen 1981, Blankenship \& Craven 1982, Park et al. 1983, Svedhem et al. 1981).

Stressed, supplethally injured campylobacteria are sensitive to the antibiotics used in selective enrichment broths and agars, in particular to polymyxin B, rifampicin and ce- phalothin (Hänninen 1982, Ray \& Johnson 1984a, Ray \& Johnson 1984b, Humphrey \& Cruickshank 1985, Lai-King et al. 1985). If the primary sample contains a large number of campylobacteria, some of them may survive selective enrichment. Difficulties arise, however, with samples containing small number of campylobacteria and high levels of other bacteria. Special demands must be ascribed to methods for detection of campylobacteria because the infective dose to humans can be as low as only 500 bacteria (Robinson 1981).

Pre-enrichment is one possible method of improving detection sensitivity. The International Standardization Organization stan- 
dard of 6579-1981 recommends the use of pre-enrichment in Salmonella detection, especially for food samples. Pre-enrichment in buffered peptone water is applied to revive sublethally injured bacteria before selective enrichment. Humphrey \& Cruickshank (1983) found that recovery of the coldand freeze-stressed campylobacteria is complete in broth after incubation for $4 \mathrm{~h}$ at $43^{\circ} \mathrm{C}$ and Palumbo (1984) reported that heat-injured Campylobacter jejuni were revived in brucella broth supplemented with $\mathrm{Na}_{2} \mathrm{~S}_{2} \mathrm{O}_{3}, \mathrm{FeSO}_{4}{ }^{*} 7 \mathrm{H}_{2} \mathrm{O}$ and sodium pyruvate within $4 \mathrm{~h}$ at $37^{\circ} \mathrm{C}$. Later Humphrey et al. (1985) recommended inoculation of samples containing small number of sublethally injured campylobacteria to refrigerated broth (refrigeration for increased viscosity) and incubation of these broths for $2 \mathrm{~h}$ at $37^{\circ} \mathrm{C}$ before addition of the selective agents. Sjögren et al. (1985) recommended pre-enrichment of one of the duplicate samples in semi-solid motility test medium (Chan \& Mackenzie 1982) for $24 \mathrm{~h}$.

In the present study we compared the sensitivity of 2 low cost pre-enrichment broths with the method without pre-enrichment. We attempted to simulate real conditions of sample transport and compared the 5 most used enrichment broths and 4 most used selective agars in detecting small number of stressed campylobacteria with and without pre-enrichment.

\section{Materials and methods \\ Bacteria}

Campylobacter jejuni biotype 1 (NCTC 11385), C. jejuni biotype 2 (NCTC 11392), C. coli (NCTC 11353) and C. laridis (NCTC 11352) were obtained from the Public Health Laboratory Service, London, U.K. C. jejuni B33 (broiler origin) and C.jejuni $\mathrm{KH} 3,5616$ and 9000 (human origin) were obtained from Dr. M.-L. Hänninen, Depart- ment of Food and Environmental Hygiene, College of Veterinary Medicine, Helsinki, Finland. C. jejuni 100 (bovine origin) was isolated by the authors at the National Veterinary Institute, Helsinki, Finland.

\section{Preparation of cultures}

Organisms were grown for $20 \mathrm{~h}$ at $43^{\circ} \mathrm{C}$ in brucella broth (Difco Laboratories, Detroit, Mich., U.S.A.) supplemented with FBP (ferrous sulfate, sodium metabisulfite and sodium pyruvate all at $0.5 \mathrm{~g} / \mathrm{l}$ ). Strains were preserved in the same broth supplemented with $10 \%$ glycerol at $-70^{\circ} \mathrm{C}$. Frozen and freeze-dried strains were cultured twice in brucella broth before use.

\section{Transport and cultured media}

Transport medium. SIFF medium (Sandven et al. 1982) - Portions of $10 \mathrm{ml}$ medium were added to test tubes.

Pre-enrichment broths. $1 \%$ buffered peptone water (BBL Microbiology Systems, Cockeysville, Md., U.S.A.) and Alkaline peptone water with reducing agents (RAPW) (Wang et al. 1983) - Media portions were $10 \mathrm{ml}$ in test tubes for the first test and 90 $\mathrm{ml}$ in $200 \mathrm{ml}$ flasks for the second.

Enrichment broths and selective agars. Modified Skirrow enrichment broth and selective agar (Skirrow 1977, Balser et al. 1979, Hänninen 1981) - The modification was addition of $2 \mathrm{mg} / \mathrm{l}$ amphotericin B (E. R. Squibb et Sons Ltd., London, U.K.) to the media. Preston enrichment broth and selective agar (Bolton \& Robertson 1982) - Modified Thioglycolate-horse blood-actidone-laurylsulfate enrichment broth (THAL) (Oosterom et al. 1983) - The modification was addition of fresh defribrinated bovine blood to the media instead of lysed horse blood. Alkaline tryptose enrichment broth (ATB) and brucella agar with selective agents (ATB selective agar) (Wesley et al. 
1983). Charcoal-cefazolin-deoxycholate enrichment broth (CCD enrichment broth) and selective agar (CCD agar) (Bolton et al. 1984).

All broths were portioned $90 \mathrm{ml}$ in 200 $\mathrm{ml}$ flasks and agars $25 \mathrm{ml}$ on $\varnothing 9 \mathrm{~cm}$ Petri dishes with nodules.

\section{Incubation and identification}

All enrichment broths and selective agars were incubated under a microaerophilic atmosphere, broths for $20 \mathrm{~h}$ and selective agars for $44 \mathrm{~h}$ at $43^{\circ} \mathrm{C}$. The microaerophilic atmosphere above the liquid $(90 \mathrm{ml}$ in a 200 ml flask) and agars was achieved by evacuating gas boxes to -800 mbar and then filling them with a gas mixture containing $5 \% \mathrm{O}_{2}$, $10 \% \mathrm{CO}_{2}$ and $85 \% \mathrm{~N}_{2}$. Evacuation and filling was carried out twice.

Campylobacteria were recognized by examining wet mounts by microscopy for curved rods exhibiting darting motility and by catalase and oxidase tests. After the incubation period of the test strains when the campylobacteria were in the early stationary phase, brucella broth was diluted in $0.1 \%$ buffered peptone water (BBL). For quantitative examination the brucella broth dilutions were plated on Skirrow selective agar. Thawing drip from deep-frozen broiler carcasses, used as a source of natural contaminating flora, was examined for campylobacteria using Skirrow enrichment broth and selective agar with negative results.

\section{Test procedure}

The pre-enrichment broths comparison test: $1 \mathrm{ml}$ aliquots of tenfold brucella broth dilutions (representing from $<10$ to $<10000 \mathrm{CFU}$ of campylobacteria) were added to $10 \mathrm{ml}$ of both $1 \%$ buffered peptone water and RAPW. Five different $C$.jejuni strains were used in this test. After incubation in a microaerophilic atmosphere for $5 \mathrm{~h}$ and $20 \mathrm{~h}$ at $43^{\circ} \mathrm{C}$ the whole pre-enrichment culture was poured into a Skirrow broth, enriched and plated on Skirrow selective agar. Another experiment with contaminating flora was made by adding $1 \mathrm{ml}$ of thawing drip from a deep-frozen broiler carcass to the pre-enrichment broth before incubation (see Fig. 1).

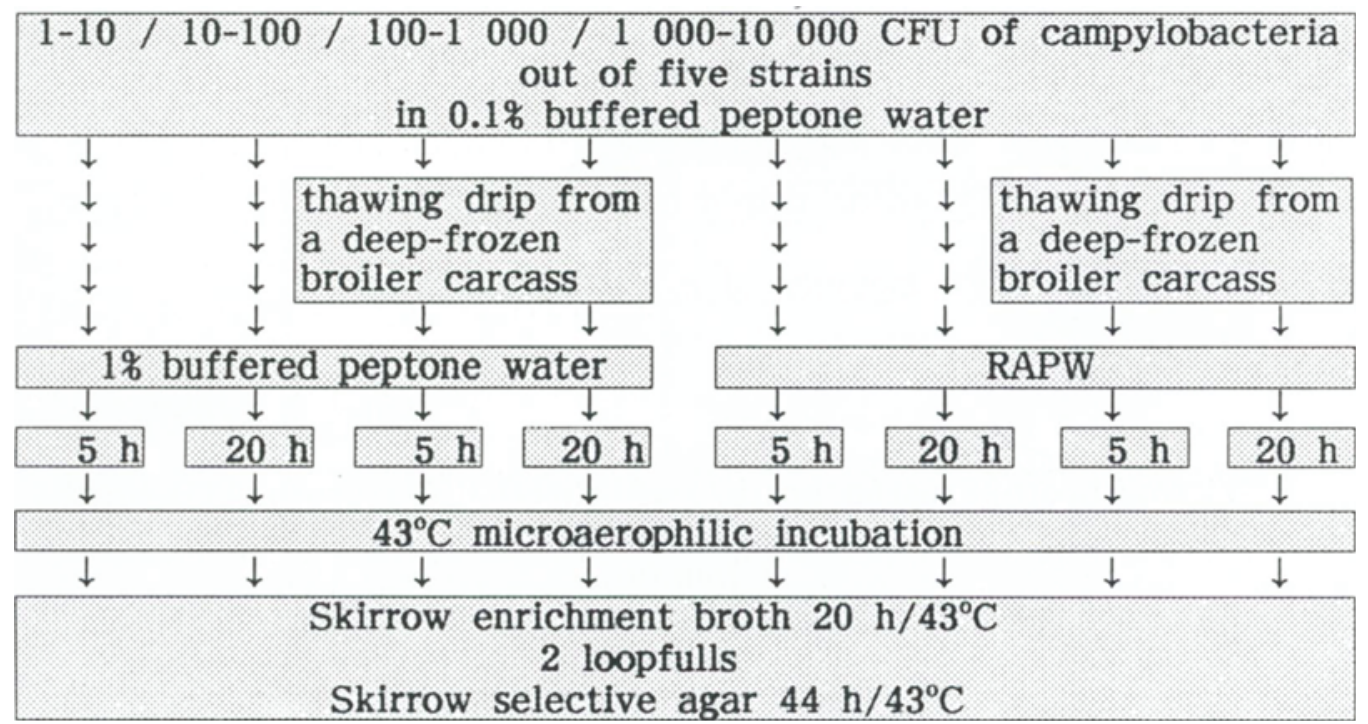

Figure 1. Test procedure for the pre-enrichment broth comparison test. 
The test simulating sample transport consisted of three experiments. Four NCTC type strains were used in this test.

In the first "transport" experiment $1 \mathrm{ml}$ aliquots of tenfold brucella broth dilutions (representing from $<10$ to $<10000 \mathrm{CFU}$ of campylobacteria) were added to five tubes containing $10 \mathrm{ml}$ of SIFF medium. Inoculated SIFF tubes were sealed and stored for 20 $\mathrm{h}$ at room temperature in the dark, transferred to Skirrow, Preston, THAL, CCD and ATB enrichment broths, incubated and plated (two loopfulls of broth) on Skirrow, Preston, Skirrow, CCD and ATB selective agars, respectively.

The second "transport with contaminating flora" experiment was carried out by adding $1 \mathrm{ml}$ of thawing drip from a deep-frozen broiler carcass to SIFF tubes before inoculation with campylobacteria. Enrichment and plating were carried out as in the first experiment.

The third "transport with contaminating flora and pre-enrichment" experiment was carried out by adding contaminating flora to
SIFF tubes and pre-enriching whole stored SIFF medium in $90 \mathrm{ml}$ of $1 \%$ buffered peptone water under a microaerophilic atmosphere for $5 \mathrm{~h}$ at $43^{\circ} \mathrm{C}$. After incubation 10 $\mathrm{ml}$ of pre-enrichment broth was transferred to enrichment broths and plated as in the first experiment (see Fig. 2).

\section{Results and discussion}

The results of the pre-enrichment broth comparison test are presented in Tables 1 and 2. Results of the test simulating sample transport are shown in Fig. 3.

The sensitivity of the campylobacter detecting methods was improved by using preenrichment with $1 \%$ buffered peptone water. Another pre-enrichment broth, alkaline peptone water with reducing agents (RAPW), was inhibitory to 4 of the strains used in this study. The concentration of cysteine $(0.25 \mathrm{~g} / \mathrm{l})$ and sodium thioglycolate $(0.5 \mathrm{~g} / \mathrm{l})$ used in the RAPW medium could have created an anaerobic environment under reduced oxygen atmosphere and partly explain this phenomenon. When contamin-

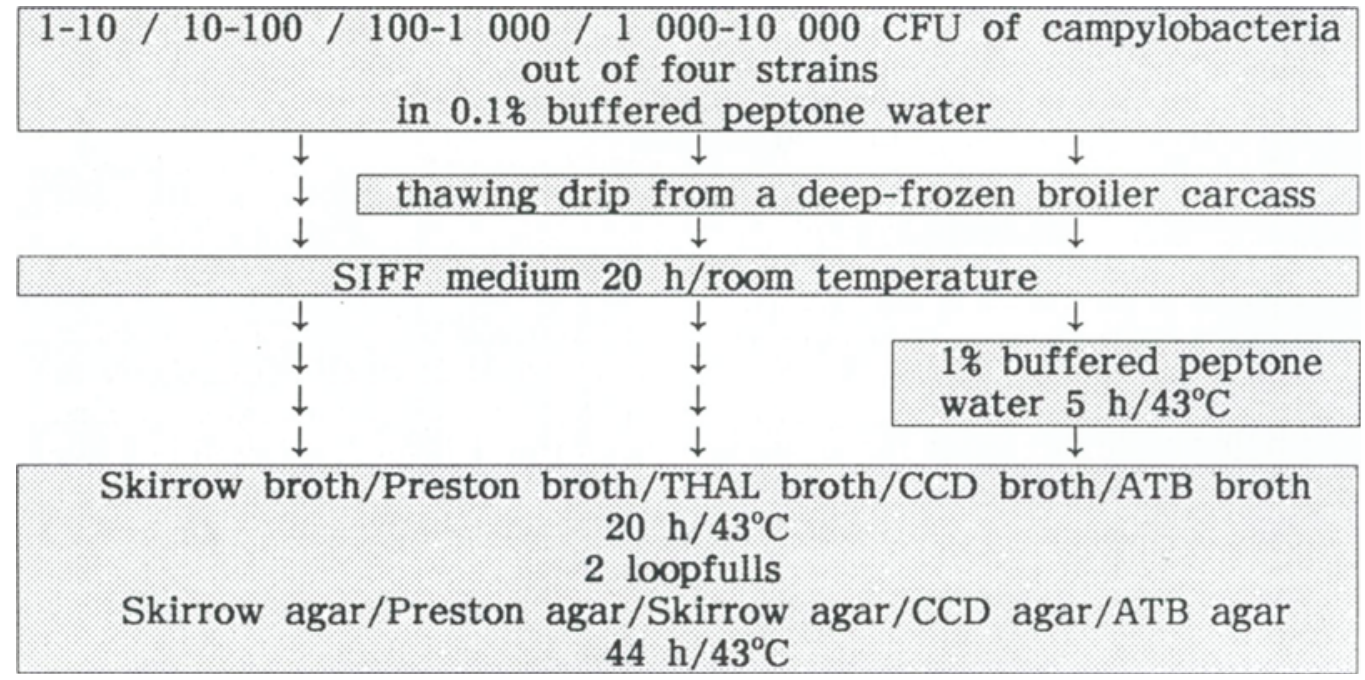

Figure 2. Test procedure for the test simulating sample transport. 
ating flora (thawing drip from a deep-frozen broiler carcass) was added, it was still possible to detect smaller number of campylo-

Table 1. Smallest number of campylobacteria out of 5 strains which could be detected using brucella enrichment broth and brucella blood agar supplemented with Skirrow antibiotics. The sample was first pre-enriched in $1 \%$ buffered peptone water $(1 \% \mathrm{PW})$ or in alcaline peptone water with reducing agents (RAPW) under a microaerophilic atmosphere for $5 \mathrm{~h}$ and for $20 \mathrm{~h}$ at $43^{\circ}$.

\begin{tabular}{|c|c|c|c|c|c|}
\hline \multirow[b]{2}{*}{ strain } & \multirow[b]{2}{*}{ control } & \multicolumn{2}{|c|}{$\begin{array}{l}\text { pre-enrichment } \\
\text { for } 5 \mathrm{~h}\end{array}$} & \multicolumn{2}{|c|}{$\begin{array}{l}\text { pre-enrichment } \\
\text { for } 20 \mathrm{~h}\end{array}$} \\
\hline & & $1 \% \mathrm{PW}$ & RAPW & $1 \% \mathrm{PW}$ & RAPW \\
\hline 100 & 2700 & 400 & $>4000$ & 60 & a \\
\hline 9000 & 70 & n.t. ${ }^{b}$ & n.t. & 70 & - \\
\hline KH3 & 4200 & $>30000$ & $>30000$ & 60 & - \\
\hline 5616 & 3200 & n.t. & n.t. & 320 & - \\
\hline B33 & 360 & 1500 & 1500 & 90 & - \\
\hline
\end{tabular}

a $-=$ not grown in this pre-enrichment broth (required inoculation was $>10000 \mathrm{CFU}$ )

$b^{b}$.t. $=$ not tested

Table 2. Smallest number of campylobacteria out of 5 strains which could be detected from contaminating flora using brucella enrichment broth and brucella blood agar supplemented with Skirrow antibiotics. The sample was first pre-enriched in $1 \%$ buffered peptone water $(1 \% \mathrm{PW})$ or in alcaline peptone water with reducing agents (RAPW) under a microaerophilic atmosphere for $5 \mathrm{~h}$ and for $20 \mathrm{~h}$ at $43^{\circ}$ and thawing drip from a deep-frozen broiler carcass as a source of contaminating flora was added to samples.

\begin{tabular}{|c|c|c|c|c|c|}
\hline \multirow[b]{2}{*}{ strain } & \multirow[b]{2}{*}{ control } & \multicolumn{2}{|c|}{$\begin{array}{l}\text { pre-enrichment } \\
\text { for } 5 \mathrm{~h}\end{array}$} & \multicolumn{2}{|c|}{$\begin{array}{l}\text { pre-enrichment } \\
\text { for } 20 \mathrm{~h} \\
\end{array}$} \\
\hline & & $1 \% \mathrm{PW}$ & RAPW & $1 \% \mathrm{PW}$ & RAPW \\
\hline 100 & 800 & 1700 & 1700 & $\mathrm{C}^{\mathrm{a}}$ & C \\
\hline 9000 & 100 & 1 & 1 & C & $\mathrm{C}$ \\
\hline $\mathrm{KH} 3$ & 1100 & 1100 & $>1000$ & C & $\mathrm{C}$ \\
\hline 5616 & 9400 & 1600 & $>1600$ & C & $\mathrm{C}$ \\
\hline B33 & 730 & 130 & $>1300$ & C & $\mathrm{C}$ \\
\hline
\end{tabular}

a $\mathrm{C}=$ plate contaminated completely

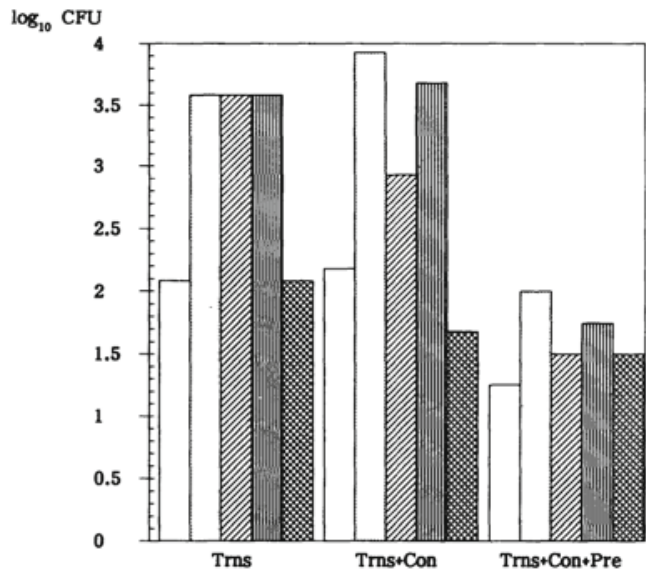

Identification methods:

Skirrow $\square$ Preston $\square$ THAL $\square$ ATB $\square \quad$ CCD

Figure 3. Test simulating sample transport. Smallest number of campylobacteria detected by five different methods with and without contaminating flora or pre-enrichment. Transport simulation (Trns) was $20 \mathrm{~h}$ storage in SIFF media at room temperature. Source of contaminating flora was $1 \mathrm{ml}$ of thawing drip from a deep-frozen broiler carcass (Con). Pre-enrichment (Pre) was carried out $5 \mathrm{~h}$ in $1 \%$ peptone water.

See text for test procedure.

bacteria after $5 \mathrm{~h}$ pre-enrichment than without pre-enrichment.

Microbiological laboratories face another special problem with environmental samples which contain low number of campylobacteria. Rollins \& Clowell (1986) showed that campylobacteria change into a nonculturable state within 2-3 weeks in aquatic environments at 25 or $37^{\circ} \mathrm{C}$. This change can also be seen in the morphology of the bacteria: Moran \& Upton (1987) reported loss of spiral morphology after prolonged incubation on solid media. The nonculturable state of campylobacteria has serious epidemiological implications because the cells are still viable. Change to the nonculturable state was not observed in pure cultures cultivated 
in stationary biphase culture systems but it was seen in the same system after 3 days if the culture medium was shaken. Shaking of the medium appears not to be favourable to campylobacteria.

Our results show that $5 \mathrm{~h}$ pre-enrichment in inexpensive stationary liquid media under a microaerophilic atmosphere is sufficient to revive stressed campylobacteria. If the preenrichment incubation time is prolonged, contaminant bacteria reach the exponential growth phase and easily overgrow the sample.

In the test simulating sample transport, preenrichment improved the sensitivity of all the isolation methods used (paired Student t-test, $\mathrm{p}<0.01$ ). The most sensitive methods tested were those with limited antibiotic supplementation, CCD and Skirrow (paired Student t-test, $\mathrm{p}<0.01$, with the exception of the Skirrow and THAL methods comparison, in which the Skirrow method was more sensitive with $\mathrm{p}<0.05$ ). The contaminating flora also appeared most often on these agars. Low concentrations of polymyxin B (2 $500 \mathrm{IU} / \mathrm{l})$ and the absence of rifampicin in the Skirrow antibiotic supplementation and the only antibiotic, cefazolin $(10 \mathrm{mg} / \mathrm{l})$, in CCD antibiotic supplementation do not restrict the growth of campylobacteria but are also insufficient to inhibit contaminating flora.

When a pre-enrichment step in $1 \%$ buffered peptone water under a microaerophilic atmosphere for $5 \mathrm{~h}$ at $43^{\circ} \mathrm{C}$ was added to the method, it was possible with CCD and Skirrow methods to detect fewer than $100 \mathrm{CFU}$ of campylobacteria from SIFF medium which was stored for $20 \mathrm{~h}$ at room temperature after inoculation.

\section{References}

Blankenship LC, Craven LC: Campylobacter jejuni survival in chicken meat as a function of temperature. Appl. environ. Microbiol. 1982, 44, 88-92.
Blaser MJ, Berkowitz ID, LaForce FM, Cravens $J$, Reller $L B$, Wang $W$ - $L L$ : Campylobacter enteritis: clinical and epidemiolocical features. Ann. intern. Med. 1979, 91, 179-185.

Bolton FJ, Robertson L: A selective medium for isolating Campylobacter jejuni/coli. J. clin. Pathol. 1982, 35, 462-467.

Bolton FJ, Hutchinson DN, Coates D: Blood-free selective medium for isolating of Campylobacter jejuni from feces. J. clin. Microbiol. 1984, 19, 169-171.

Chan FTH, Mackenzie AMR: Enrichment medium and control system for isolation of Campylobacter fetus subsp. jejuni from stools. J. clin. Microbiol. 1982, 15, 12-15.

Doyle MP: Campylobacter in foods. In: Butzler JP (ed.): Campylobacter Infections in Man and animals. CRC Press, Inc., Boca Raton 1984, pp. 163-180.

Humphrey TJ, Becket P, Cruickshank JG: A technique for the isolation of sub-lethally injured Campylobacter jejuni from foodstuffs and its application in a study of the influences of drinking water source and milking hygiene on the levels of $C$. jejuni in raw milk. In: Pearson AD, Skirrow MB, Lior H, Rowe B (eds.): Campylobacter III. Public Health Laboratory Service, London 1985, pp. 64-65.

Humphrey TJ, Cruickshank JG: Sub-lethal injury and campylobacters. In: Pearson AD, Skirrow MB, Rowe B, Davies JR, Jones DM (eds.): Campylobacter II, Proceedings of the Second International Workshop on Campylobacter Infections. Brussels, 6.-9. September 1983. Public Health Laboratory Service, London 1983, pp. 51-52.

Humphrey TJ, Cruickshank JG: Antibiotic and deoxycholate resistance in Campylobacter jejuni following freezing and thawing. J. appl. Bact. 1985, 59, 65-71.

Hänninen $M-L$ : Survival of Campylobacter jejuni/ coli in ground refrigerated and ground frozen beef liver and in frozen broiler carcasses. Acta vet. scand. 1981, 22, 566-577.

Hänninen $M-L$ : Effect of recovery medium on the isolation of Campylobacter jejuni before and after heat treatment. Acta vet. scand. $1982,23,416-424$. 
International Standardization Organization: Microbiology - general guidance on methods for the detection of Salmonella. ISO 6579-1981 (E).

Lai-King $N G$, Taylor DE, Stiles $M E$ : Are campylobacters always resistant to antibiotics used in selective media? In: Pearson AD, Skirrow MB, Lior H, Rowe B (eds.): Campylobacter III. Public Health Laboratory Service, London 1985 , pp. 61-62.

Moran AP, Upton ME: Factors affecting production of coccoid forms by Campylobacter jejuni on solid media during incubation. J. appl. Bact. 1987, 62, 527-537.

Oosterom J, Notermans $S$, Karman B, Engels $G B$ : Origin and prevalence of Campylobacter jejuni in poultry processing. J. Food Prot. 1983, 46, 339-344.

Palumbo SA: Heat injury and repair in Campylobacter jejuni. Appl. environ. Microbiol. 1984, 48, 477-480.

Park CE, Stankiewicz ZK, Lovett J, Hunt J, Francis $D W$ : Effect of temperature, duration of incubation and $\mathrm{pH}$ of enrichment culture on the recovery of Campylobacter jejuni from eviscerated market chickens. Can. J. Microbiol. 1983, 29, 803-806.

Ray B, Johnson C: Sensitivity of cold-stressed Campylobacter jejuni to solid and liquid selective environments. Food Microbiol. 1984a, 1, 173-176.

Ray B, Johnson C: Survival and growth of freezestressed Campylobacter jejuni cells in selective media. J. Food Safety 1984b, 6, 183-195.

Robinson DA: Infective dose of Campylobacter jejuni in milk. Brit. Med. J. 1981, 282, 1584.

Rollins DM, Colwell RR: Viable but nonculturable stage of Campylobacter jejuni and its role in the natural aquatic environment. Appl. environ. Microbiol. 1986, 52, 513-538.

Sandven $P$, Solberg $O$, Ødegaard $K$, Myhre G: Improved medium for the transportation of gonococcal specimens. Acta pathol. microbiol. immunol. scand. Sect. B. 1982, 90, 73-77.
Sjögren E, Lindblom G-B, Kaijser B: Optimal transport and enrichment methods for the isolation of Campylobacter jejuni. In: Pearson AD, Skirrow MB, Lior H, Rowe B (eds.): Campylobacter III. Public Health Laboratory Service, London 1985, pp. 62-63.

Skirrow MB: Campylobacter enteritis: a "new" disease. Brit. Med. J. 1977, 2, 9-11.

Svedhem A, Kaijser B, Sjögren E: The occurrence of Campylobacter jejuni in fresh food and survival under different conditions. J. Hyg., Camb. 1981, 87, 421-425.

Wang W-LL, Reller LB, Smallwood B, Luechtefeld $N W$, Blaser $M J$ : Evaluation of transport media for Campylobacter jejuni in human fecal specimens. J. clin. Microbiol. 1983, 18, 803-807.

Wesley RD, Swaminathan B, Stadelman WJ: Isolation and enumeration of Campylobacter jejuni from poultry products by selective enrichment method. Appl. environ. Microbiol. 1983, 46, 1097-1102.

\section{Sammanfattning}

Preinkuberings- och anrikningsmetod till ett litet antal campylobacterier med kontaminering.

Färre än $100 \mathrm{CFU}$ av campylobakterier kunde isoleras ur SIFF transport medium som hade kontaminerats med smältvatten från djupfrysta broiler och som förvarats i rumstemperatur för $20 \mathrm{~h}$. Metoden bestod av 5 timmar preinkubering i $1 \%$ peptonvatten i mikroaerofil atmosfär i $43^{\circ} \mathrm{C}$ före det selektive anrikandet antingen i brucella buljong och på brucella blod agar med Skirrow antibiotika eller i kol-cefazolin-desoxycholate (CCD) anrikningsbuljong och på CCD agar. Den andra preinkuberingsbuljongen studerats var alkalisk pepton vatten med reducerande medel (RAPW) och andra buljonger och plattor var Prestonbuljong och -medium, THAL-buljong och alkalisk trypton buljong (ATB) och brucella agar med ATB-antibiotika. Kontaminering av plattorna kan vara ett problem när man använder anrikningsbuljonger och selektiva medier med begränsad dosering av antibiotika.

(Received April 5, 1988).

Reprints may be requested from: Matti Aho, National Veterinary Institute, P. O. Box 368, SF-00101 Helsinki, Finland. 
